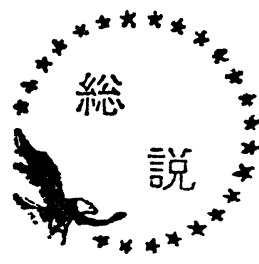

\section{1 まえがき}

1966年の末, カナダに派遣されたオイルサント調查 団（団長, 故㒇田隆門東大教授）に参加する機会を与 えられて以来, 第 2 次調查団 (団長, 徳久寛東北大学 名䓂教授）その他の現地視察, さらには最近, ベネズ エラ訪門の機会にも恵まれた。昨年秋以来のいわゆる 石伷危機にあたって，オイルサンド資原に関する世の 関心もようやく高まりつつあるように見える。この機 会にオイルサンド資傆開発のその後の進展と将来の発 展のための技術的課題なとについて，筆者の限られた 知見の範囲てはあるか, 紹介させて頂きたい。なお, すてに本誌その他に 報告 させて頂いた記事 ${ }^{122)}$ と若干 の重複する点かあることを御了承願いたい。

さて, 昨年秋の第 4 次中東践争を契機として世界は 㛊刻なエネルキー危機にみまわれた。国内にみるべき エネルギー資㥳をもたす，全エネルギー需要のおよそ $70 \%$ を輸入に依存し，しかもその大部分か中東の石伷 てあるわか国においては，この危機にあたって最も大 きな混乱を生したのは周知のとおりてある。

今回の石伷危機の直接的原因は石伷をめくる世界の 諸勢力の政冶的，経斉的葛藤にある之考えられ，また その背景には第 2 次大栈後のエネルギー梳体化革命の 結果としての石伷への過度の依存，石伷を含む一次産 品の相対的価格低下, 南北問題の顕在化なとがあろ ら。したかってその解仭はすくれて国際政冶的なアプ ローチを必要とする問題てある。有限の地球の資原を 全人類の引続く, 長期にわたる福祉, 繁栄のために, 如何に配分するか, 佸用してゆくかか本質的な課題て ある。

エネルギー資原についてみれは，地熱，太陽熱，あ るいは核融合なと莫大な譛在資塬の利用技術か開発の 緒につこうとしているか，その本格的実用化には大き なリード・タイムか必要てあり，今世紀に関する限 り，化石然枓への依存から大きく脱却することは事実 上困難てあろう。しかし，今回の石伷危機の経験から も, 石伷一の一辺倒的依存はわか国を含む先進工業諸
東京大学 工学部

付属総合試験所 冨 永 博 夫

国にとって好ましいことてはなく，また産伷諸国の望 むところてもない。すなわち，化石然料の多様化か， それらのクリーン・エネルギーへの変換と有効利用と ともに, 当面のエネルギー技術開発の主要課題一つて あることには異論がないてあろう。

化石然料としては天然ガス, 石伷, 石炭の 3 者か最 も代表的なものてあるが，未利用資原としてオイルシ エールおよびオイルサンドかある。とりわけオイルサ ンドは石伷に最も近い炭化水素資原てあり, 後述する ように，その資原埋蔵量か大きく，その地理的分布か 石伷とは異なって西半球の南北アメリカ大陸に存在 し，しかもそれらの鈗床はすてに確認されていて探鉣 リスクは考えなくて良い。

そのらえオイルサンドの採伷，精製技術の実用性 活，露天掘り佉に関する限り1967年秋以降の GCOS 社の商業生産により，すてに証明されており，また経 闵性についても，昨今の原油価格水隼か大きく低落し ない限り，十分に成立するとみてよい。ただしオイル サンド資原の本格的開発のためには，伷層内採収技術 の確立になお問題かあり，今後の努力に待つところが 少なくない。

オイルサンド資原の開発に関する上記の諸問題につ いて以下に概説したい。

\section{2 オイルサンド資源の評価}

カナダ・アルバータ州の Oll and Gas Conservation Act によれは，オイルサンドは，通常の生産方法によ っては坑井から天然の状態のまま採取できないほと高 い粘度をもつ炭化水素油を含む砂，と定義している。 このオイルサンドは以前はタールサンドと呼はれてい たが, この炭化水素油の成因, 性状からみて, 有機物 の熱分解によって生成するタールとは異なるといら理 由から，オイルサンドと改称されたものてある。この 定義（かならすしも一般的な承認を得たものてはない か）からも知られるとおり，オイルサンドに含まれる 炭化水素伷は重質（約 $10^{\circ}$ API 以下）の原伷てはあ るが，従来知られている原伷とまったく別種のものと 
いうわけではない。言い換えればオイルサンドと重質 原油の区分は厳密なものではなく, 両者は連続的なも のである。

表 1 は M Clegg が1973年の英国石油学会の夏 期集会において発表した世界の重質原油およびタール サンドの資源埋蔵量分布である ${ }^{3)}$ 。これらは, ここて いう，オイルサンド資源とみなしてよいと考える。

\section{表 1 世界のオイルサンド資源埋蔵量}

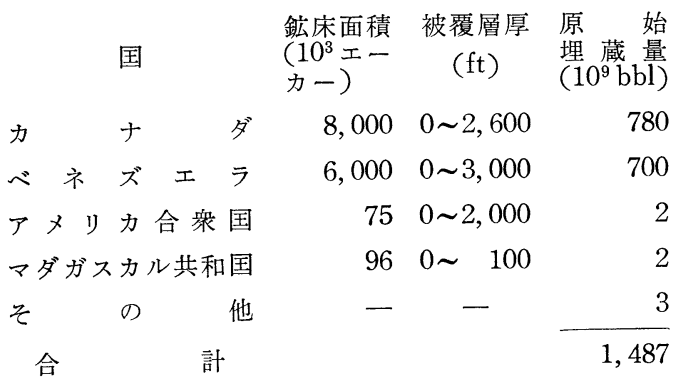

資源埋蔵量は, その定義が統一されていないことも あって，報告者によりかなり相違するのが常である が，同表の示すところによればオイルサンドの既知埋 蔵量約 1 兆 5 千億 $\mathrm{bbl}$ (すなわち約 2,400 億 $\mathrm{k} l$ ) のお よそ半分がそれぞれカナダ (アサバスカ地域)および ベネズエラ（オリノコ河北岸流域）に存在し，これら 両者が自由世界のオイルサンド資源のほとんどすべて を占める現状である。とはいっても，後述するとお り，これらカナダおよびベネズエラのオイルサンド鉱 床の油層工学的情報の精度と確度, ならびに開発段階 には大きな差が存在し，両者を単純に比較することは 合理的ではない。

すなわち，カナダのオイルサンド資源については， 古く19世紀末頃から科学的調查が開始され，1919年に Research Counc1l of Alberta が創設されてからは一 段と調査が進み，政府扔よび民間企業による数千本の コアリングや試掘が行なわれ, その地質学的, 油層工 学的実態はほぼ全貌が明らかにされているといってよ いであろう。

図 1 亿示したとおり，カナダのオイルサンド資源は アルバータ州の首都エドモントンの東北約 280 マイル に位置するフォートマクマレーを中心とするアサバス カその他の地域に賦存している。このオイルサンド資 源の埋蔵量については地理別, 油層深度別, 含油率別 に発表されているが，表 2 は1973年秋，アルバータ州 の Energy Resources Conservation Board の G W. Govier が C.S P.G. シンポジウムに発表した論文 ${ }^{4)}$

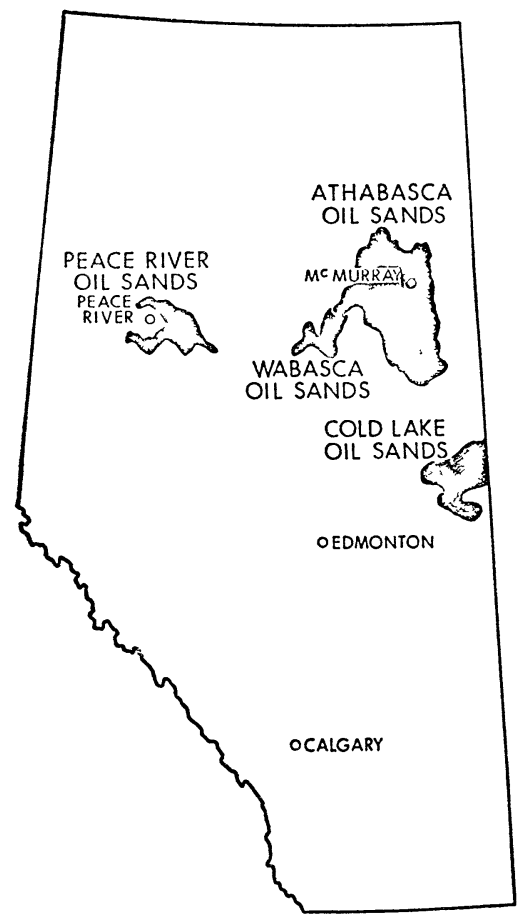

図 1 カナダ・アルバータ州のオイルサンド資源

\section{表 2 カナダのオイルサンド資源埋蔵量}

地 被覆層保度 原始*1 可採埋 合成 $* 4$ (ft) 量 $\left(10^{9} \mathrm{bbl}\right)$ 原㣙

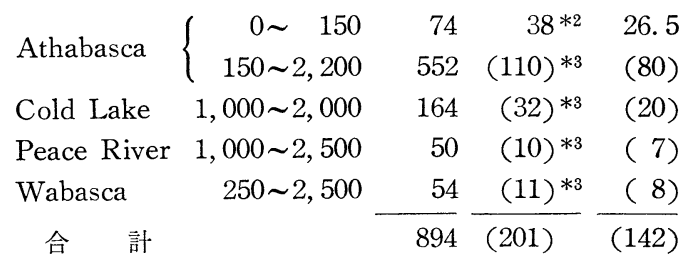

（注） *1 含油率 $2 \mathrm{wt} \%$ 以上

*2. 含伷率 $5 \mathrm{wt} \%$ 以上でストリッピング比 1 以下

*3. 伷層内回収効率 $20 \%$ 仮定

*4. 分離抒よび変換効率, 計 $70 \%$ を仮定

をもとに作製したものである。

この表によれば，含油率 $2 \mathrm{wt} \%$ 以上の鉱床に存在 する原油の原始埋蔵量 (bitumen in place) は 8,940 億 bbl とされている。このらち約70\%にあたる 6,260 億 bbl がアサバスカに存在するが，これを被覆層深 度別に分類寸れば， $0 \sim 150 \mathrm{ft}$ のものが 740 億 bbl, $150 \sim 2,000 \mathrm{ft}$ のものが 5,520 億 bbl である。またコ 一ルド・レーク, ピース・リバー, ワバスカ各地域の埋 蔵量は限られており, いずれも被覆層深度が大きい。 
これらオイルサンド資源の可採率は技術と経済の関 数であって, 時代とともに変遷するであろらが, 現在 の技術, 経済水準において可採とみなし得る確認可採 埋蔵量は 380 億 bbl である。これは被覆層深度が 0
$150 \mathrm{ft}$ であり, かつ含油率 $5 \mathrm{wt} \%$ 以上, 被覆層厚/油 層厚比 (stripping ratio) 1 以下, の条件をみたす資 源埋蔵量である。このオイルサンドを露天掘りしたの ち, 熱湯処理法などによりビチュメンを分離し,さ

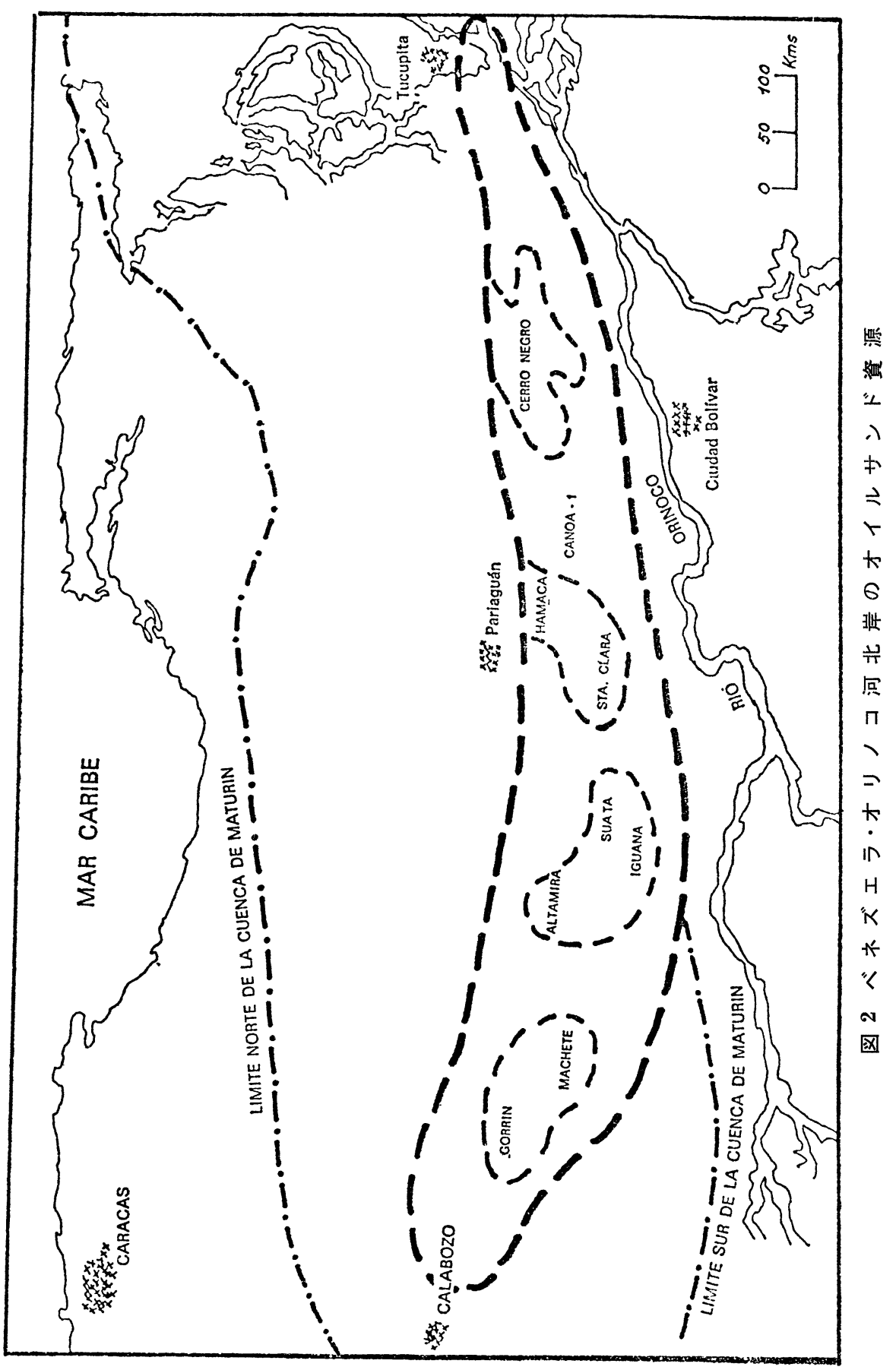


らにコーキング，水素化脱硫なとの精製工程にかけれ ば合成原伷が生産される。これらの分離および変換 （conversion）効率をあわせて70\%とみれは，合成原 油生産量は約 265 億 bbl となる。

被覆層深度の大きい場合, 露天掘り工法は適用し難 いのて, 後述のような伷層内採収技術の採用か必要て あるが，この技術は現在，フィールドテストの段階に あり，完全に実用化されているとはいい難い。仮にこ の種の技術により $20 \%$ か回収可能になるとすれはさら に約 1,630 億 bbl のビチュメンが得られ，これから約 1,150 億 $\mathrm{bbl}$ の合成原油が生産されるものと推定され ている。表 2 の可採埋蔵のうち括弧つきの数值はこの 意味での推定值てある。

ともあれ，これら確認および推定可採埋蔵量の合計 はビチュメンとして約 2,010 億 bbl (約 320 億 $\mathrm{k} l$ ), これから生産される合成原油は約 1,420 億 bbl（約 226 億 $\mathrm{k} l$ ) とみなせる。

次にベネズエラのオイルサンド資源については, 表 1 に示した 7,000 億 bbl といら值があり, またべネズ エラの鉱山石油省の Jose A Galavis S, および CVP (国営石油会社)の Hugo M Velarde Ch 両氏の推 定による 6,925 億 bbl といら值も知られている。一方 Anibal R Martmez 博士心表 3 に示したように920億 $\mathrm{k} l$ (約 5,790 億 $\mathrm{bbl}$ ) という推定值を発表している5)。

\section{表 3 ベネズェラのオイルサンド資源埋蔵量 \\ 地 \\ 域}

Gorrın-Macheta

Altamıra-Iguana-Suata

Hamaca-Santa Clara

Cerro Negro

合

計

(注) ${ }^{*}$. $579 \times 10^{9} \mathrm{bbl}$

このようにベネズエラのオイルサンド資源埋蔵量に 関する見解は未だ確定していない。その理由は地質学 的, 伷層工学的な調査が不十分なためてある。すなお ちこの資源の発見は古く1935年にさかのほるとはい え，重質原伷てあるため商業的魅力に乏しいことか ら，40本程度の試錐が行なわれたままに放置されて来 たものてある。しかし最近の石油情勢の変化により， ベニズエラ国の鉱山石伷省と国営石伷会社 CVP は, 目 2 に示すオリノコ河北岸東西 $600 \mathrm{~km}$, 南北 $50 \mathrm{~km}$ にわたって分布する主要 4 地域について, 1973年から 5 ケ年計画によって合計約 300 本の試掘調查を行ない
つつあり，これが完成すれは資原埋蔵量や原伷の特性 もかなり明らかになるものと期待される。

ともあれ現時点での前記の J A Galavis らの推定 計算の根拠法次のと抒りてある。すなわちオイルサン ド蹠床の容積約 $1,239 \times 10^{6}$ acre・ft に安全係数 $1 / 2$ を 乗し, 孔隙率平均25\%（12３8\%にわたって変化す る), 孔隙部分の含伷率平均 $60 \%$ (30 90\%), 容積縮 少率 (Shrinkage factor) 0 96, さらに acre・ft から bbl への換算係数 7,758，をそれそれ乗して，6,295 億 $\mathrm{bbl}$ が算定されたものてある。以上の基礎情報が正 しいものてあり，また回収率か $10 \%$ てあると仮定すれ は, 約 630 億 $\mathrm{bbl}$, 寸なわち約 100 億 $\mathrm{k} l$ の原油の生 産が期待されることになる。ちなみにオリノコ・オイ ル・ベルトと呼はれるこの地域のオイルサンド鈶床の 油層梁度は大部分か 200 1,000m にあり，カナダ・ アサバスカのように露天掘り工法の適用は困難てある とみられている。

以上に述ベたとおり，オイルサンド資原の評価には 不確定要素か少なくないか, 可採原伷埋蔵量としてお おまかに汸力ナダに 320 億 $\mathrm{k} l$, ベネズエラに 100 億 $\mathrm{k} l$ が期待てきるものと考えられ，これを中東地域に 扮ける確認可採原伷埋蔵量約 500 億 $\mathrm{k} l$ と対比すれは, オイルサンド資源の潜在的可能性は自ら明らかてあろ 5。

\section{3 オイルサンドからの合成原油の生産}

オイルサンドから石伷製品を生産する工程は, 通常 原油からのそれと同样にアップストリームとダウンス トリームの両部門に大別きれるが, オイルサンドに含 まれる原伷か重質かつ高粘度であり, 硫黄や窒素, さ らにバナジゥム, ニッケルなとの不純物含有量が多い ために, 両部門において採用される石油生産, 精製技 術には特別の工夫が必要であり, 今後の技術開発に期 待すべきものも少なくない。

まずアップストリーム部門について述べる。

アップストリーム技術は採掘去 (minng) と伷層内 採収法 (in situ recovery) に大別される。钩床梁度 および油層の厚さがこれらの技術の適用を区分する。 すなわち表土が浅く, 伷層の厚さも大きい場合は露天 掘りによって採掘てきるが, 表土が深い場合は露天掘 りは経済性を失ない, 伷層内採収法の適用が不可欠に なる。露天掘りの適用の一応の目安は表土 $150 \mathrm{ft}$ 以 内, 油層の厚さが表土と同程度とされている。また油 層内採收法は鈗床探度か $600 \mathrm{ft}$ 以上てあることが必要 とみなされている。したがって, 以上の中間の深度の オイルサンド脏床からの採油をどのようにするか，は 
現在のところよい考えはないようである。

GCOS 社は現在採掘法によっているが，その実施 区域は丘陵性の森林地帯であり, 植物の枯死体なとを 含む muskeg が散在している。この muskeg 層は 30 〜 40 ft あり, その剶土作業は muskeg が凍って固く なる冬季汇行なわれている。 muskeg の除去も含めて 剝土作業はフロント・エンド・ローダーと $150 \mathrm{t}$ トラ ック（ダンプカー）で行なわれ, 露出したオイルサン ド層はバケット・ホイール・エクスカベーター, ベル ト・ワゴン, 高速ベルトコンベアの組合せで採掘され る。図 3 参照。

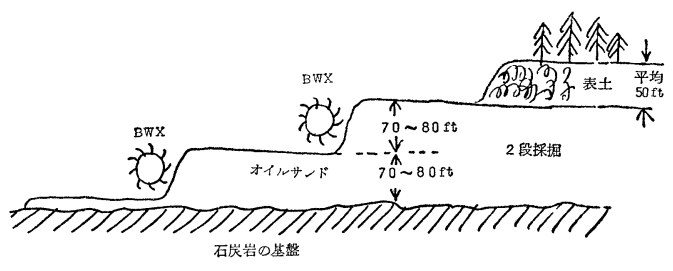

図 3 GCOS 社の露天掘り作業

この作業の規模は実に巨大なものであって, 原油 (bitumen) 65,000 bbl/日 を得るために, 約 100,000 t/日 のオイルサンドを採掘しなければならない。こ のほか表土の剝取りも含めれば, 原油 $1 \mathrm{bbl}$ あたり $2 \mathrm{t}$ 以上の固体の処理が必要でめり,このために 1 ドル近 い経費を要するものと推測される。

採掘されたオイルサンドから原油を分離する技術と しては次のようなものがある。

a. 溶媒を用いる方法

1. 熱湯処理法 Hot water process

口. 冷水処理法 Cold water process

八. 非水溶媒法

b. 分解蒸留法

イ. 直接コーキング法 Drrect coking process

これらのうち，GCOS 社が採用しているのは熱湯 処理法である。その他の方法はパイロット・プラント 段階までの開発研究はすんでいるが，実用化するには いくつかの問題点が残されている。

熱湯处理法は前報1にも紹介したとおり， K A Clark 博士 (Research Council of Alberta) によっ て考案されたプロセスであり, アルカリ性の熱湯と水 蒸気をオイルサンドに加えてパルプ状とし, 分離槽表 面に浮上した油泡を取出す方式である。すなわちアサ バスカのオイルサンドは図4 亿示したように, 水にお おわれた珪砂（粒径拈よそ $1 \mathrm{~mm}$ 以下）の間隙に原油

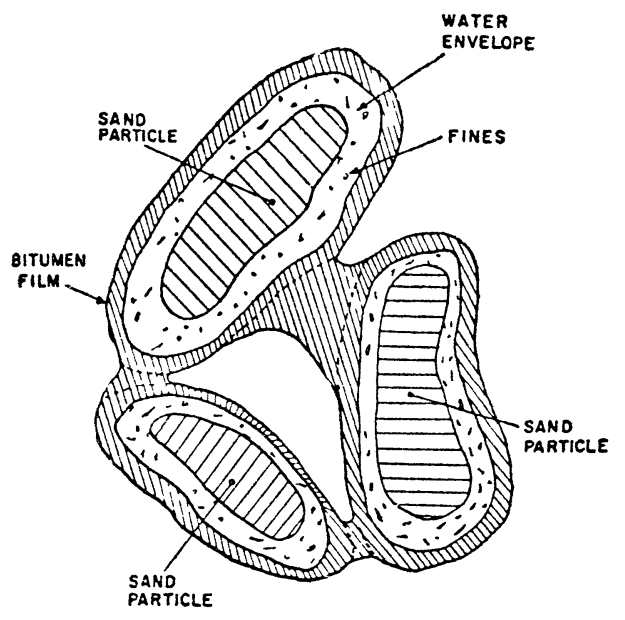

図 4 アサバスカ・オイルサンドの砂-水-油の構 造

が存在する形をとっており ${ }^{6)}$ ，この構造を破壊するた めに上記の処理法が有効である。なお油泡中には粒径 数十ミクロン以下のこまかい粘土質が含まれるので, ナフサ希釈遠心分離法でこれを除去する必要がある。

冷水処理法は Canadian Department of Mines and Technical Surveys と Imperial Oıl Enterprises Ltd. の両者によってそれぞれ独立に研究されたもので, 前 者は水のほか若干の溶媒を併用する点が異なる。これ らの方法はサンドの分離が不完全であり, かなりのサ ンドが油に伴なわれるので, b. イのコーキング法の 前処理工程として採用される可能性がある。

非水溶媒を用いて原油を抽出分離することは原理的 には優れたものであるが, 実用的観点に立つと, 溶剤 の回収率に問題があり, 大量のサンドに伴なわれて逃 げる溶剤の損失が避け難いため経済性が低いとされて いる。

直接コーキング法は Canadian Department of Mines and Technical Surveys によって研究されたもので, オイルサンドを原油の分離を行ならことなく直接に流 動床式熱分解装置へ送入し, 約 $480^{\circ} \mathrm{C}$ の温度で原油を 熱分解し，軽質化と分離を同時に達成しょうとするも のである。着想は優れているが，サンドによる装置の 磨耗や, サンドに伴なわれて逃熱の回収, なとに問題 があるといわれている。

さて, アップストリーム技術としての油層内採収法 の進歩法度の大きい鉱床の資源開発には必須の課題 である。ダルシーの放射状流動の式によれば, 定常状 態での原油の油井一の流入速度, 寸なわち原油生産量 は, 油層の渗透率と圧力差に比例し, 原油の粘度に逆 
比例する。したがって重質, 高粘度の原油を含みかっ 伷層圧力の低いオイルサンド鈜床に対し, 高温水蒸気 を吹込む，空気を圧入して着火し，部分燃焼を行な ら，またはこれらを併用するなどの熱回収法を適用す ると, 油層塭度の上昇により粘度が低下し, 水蒸気や 燃焼ガスの駆動力か加わって圧力差が増し, さらに水 蒸気の侁涤効果と孔隙の温度膨張により㑫透率を増加 する, なとの理由により, 原伷の生産速度か向上する ことが期待てきる。

水蒸気圧入法, 伷層内然焼佉なとの技術はアメリ カ, カナダ, ベネズエラなとの重質原伷（一般には $20^{\circ}$ API 以下，すなわち Sp Gr 0934 以上）につ いてすでにフールドテストや商業生産か行なわれ， 相当の成功を見ているものてある。

アサバスカのオイルサンドの場合は, 原油の飽和し た状態ての伷層の倅透率はゼ口に近いため, ます伷層 を破砕して外部エネルギー流体のための通路を作る必 要があり,ここに一つの技術開発課題がある。

Pan American Petroleum Co はそのカナダにお ける子会社 Muskeg Oil Co の钩区において Cofcaw 法の技術開発を行なった。この方法は圧入井の生産井 より配置し, 油層に対して水圧破砕を実施したのち, 前向燃焼を行なって $200^{\circ} \mathrm{F}$ 程度まで伷層を加熱し， ついて空気抢よび水を圧入して原伷の油層内移動を実 現する。フィールド・テスト結果によれは伷層内ピー ク温度は $1,500^{\circ} \mathrm{F}$ てあり, 産出された原由の比重は $8 \sim 14^{\circ}$ API で，含硫率は $2 \%$ 台に低下した ${ }^{7)}$ 。Muskeg O ll Co はこの技術を利用するオイルサンド商業 生産計画を 1968 年に申請したが，規模拡大に伴な ら諸問題についてさらに研究を行なら必要がある との理由により, 認可の直前に自ら申請撤を回し た。

他方, Shell Canada Ltd は1963年にオイルサンド 商業生産の申請を行ない, 水蒸気圧入佉のパイロット ・テスト結果を発表した。この場合, 坑井間隔は $50 \mathrm{ft}$ で，生産井を中心として 4 隅に压入井を配置する 5 点 法をとり, 1 坑あたり水蒸気注入量 100t/日として, 生産井 1 坑あたり $200 \mathrm{bbl} /$ 日 の産伷量を実現し, 回 収率は 50〜70\%といら高い值を得たといわれる7。 Shell のこの申請は 合成原伷市場の点に問題かあり, 認可されないままてあるか，近い将来にはこの伷層内 採収技術が日の目を見ることは間違いないであるう。

次にダウンストリーム部門の技術的問題について述 ベよう。

オイルサンドから分離, 回収される原伷は, カナ
ダ, ベネズエラのいずれの場合も, 重質 ( 6 ～9 $\mathrm{A}$ API), 高粘度てあり, 硫黄 (4〜6wt), 窒素(0 3 0 6 wt \%), 酸素 (0 2 2 $\mathrm{wt} \%)$, バナジウム $(200 \sim 600 \mathrm{ppm})$, ニッケル $(80 \sim 200 \mathrm{ppm})$, 鉄, 銅なとの不純物を多量 に含んている。しかし，灯軽伷相当の佛点成分も $10 \%$ 前後含まれ, また减圧蒸留汇よって留出可能な留分 （坲点約 $540^{\circ} \mathrm{C}$ 以下）の含有量も50\%程度はある。こ の意味からすれは中東産原伷の常圧蒸留残油よりも取 扱いやすいともいえる。

以上は採掘一熱偒処理佉（またはこれに隼する分離 法）によって生産された場合の原伷の性状てある。伷 層内採収佉によって生産された原油恃上記よりやや軽 質てあるものと予想されるか，具体的には適用技術の 種類や条件によって変動するてあろう。

ともあれこのオイルサンド原伷の精製が必要である ことは当然てあり，目的に応していくつかの技術の組 合わせが必要になる。すなわち,

\section{a 粘度の低下}

オイルサンド原伷は粘度か高く, そのままてはパ イプライン輸送む困難である。钩床近傍の製伷所と して要求される最低限の加工は粘度低下のための熱 的もしくは接触的水素化ビスブレーキングてある。

$\mathrm{b}$ 軽 質 化

市場の需要構造に応し, また付加価値の向上のた めに, 原㣙を分解して軽質留分の得率の向上をはか る。このためコーキング, 水素化分解, 接触分解な との方法かある。

c 不純物の除去

製品品質の向上のために直接または間接水素化脱 硫 (精製) を行なう必要かある。間接脱硫のために コーキング，傛剤脱歴なとを採用すると，脱アスフ アルト, 脱金属には有効て以後の精製工程の技術的 困難性は大きく軽减されるか, アスファルトやコー クスの処分に工夫か必要になる。

\section{$\mathrm{d}$ その他}

ガソリンのオクタン価向上のための接触改質, 灯 伷の燃燒性改善のための高圧水素化, その他の精製 工程か市場の要求に応して付加される。

GCOS社か現在アサバスカの現地て実施している精 製工程はすてに紹介したとおり1，ディレード・コー キングとユニファイニングを基本とするものて, 付帯 設備として水素製造装置, 硫化水素分離装置, およひ 硫黄回収装置がある。

この精製工程から生産される合成原伷は $36 \sim 38^{\circ} \mathrm{C}$ API で, 硫黄分 $01 \mathrm{wt} \%$ 程度の優れた品位をもって 
いる。各留分の含有量は, ライトナフサ 7 $10 \mathrm{vol} \%$, ヘビーナフサ 16 20vol\%, 灯油 15 20vol\%, 軽油 $33 \sim 36 \mathrm{vol} \%$, 残油 (沸点 $350 \sim 450^{\circ} \mathrm{C}$ ) $15 \sim 20 \%$ であ る。すなわち原油といらよりも中間製品 (留出油) の 混合物である。この合成原油のエドモントンに拉ける パイプライン渡し価格は昨年秋において $3.98 \mathrm{c} \$ / \mathrm{bbl}$ であった。この価格は合成原油の全生産コストを十分 につぐならものであるとみて良い。

公表されている生産計画によれば, 合成原油 45,000 $\mathrm{bbl} /$ 日 が原油 $57,700 \mathrm{bbl} /$ 日を原料として生産され，こ の数字からみるかぎり, 合成原油の得率は約 $78 \mathrm{vol} \%$ である。このほかコークス $2,600 \mathrm{t} /$ 日, 硫黄 $314 \mathrm{t} /$ 日 が生産される。前者の一部は自家然料として消費され るが，相当の余剰を生じ, 硫黄とともにその処分が問 題になっている模様である。

オイルサンド原油からの合成原油得率の向上は, 資 源有効利用の観点からも, また昨今の原油価格の高い 水準に拉いては経済性の視点からも, 望ましいことで あり, 一層の技術的工夫が要求されよう。

Syncrude 社の A. W. Hyndman はフルードコーカ 一, ハイドロビスブレーカー, および真空蒸留の工程 を組合わせ, 通常の水素化脱硫に適するオイルサンド 原油の一次分解スキームの設計の可能性を種々検討し た結果を報告している8)。それによればオイルサンド をまずハイドロビスブレーキング (60\%転化率) し， その生成物を真空蒸留して残油をフルードコーキング
することにより，対原油 $90 \%$ 以上の収率で合成原油を 生産し得る。

\section{4. オイルサンド資源開発の将来と課題}

オイルサンド資源は在来の石油にもっとも近い炭化 水素資源であり，その埋蔵量の規模も大きい。さらに その採取，精製技術も石油産業の既存技術の応用，発 展の線上にあるといえる。この意味において，化石然 料の多様化の要請に応え得るもっとも有力な資源であ り，その将来に対する期待は大きい。

ベネズエラについては, 現在オイルサンドの資源調 査と油層内採取技術の開発が緒についたばかりの段階 にあり，未だ不確定な要因が多く，1970年代における 本格的開発を期待することは困難であろう。

カナダについては1967年秋の GCOS 社の商業生産 開始以来, 当初は若干のトラブルも伝えられたが, 現 在はまったく順調に操業が続けられ, その生産規模も 1972年には $51,000 \mathrm{bbl} /$ 日 に達し, 近く $65,000 \mathrm{bbl} /$ 日 への拡大の認可もおりるものと予想される。

この GCOS 社の生産に加えて, 表に示したとおり, Syncrude 社の商業生産計画がすでに認可されて目下 プラント建設が進行中であり，1977年には操業開始の 予定である。この生産規模は 1984 年には $125,000 \mathrm{bbl} /$ 日に達する予定である。

以上の確定的な計画のほかに, Shell, Cities Service, Muskeg Oil など各社の申請が目白押しの状態である。 これら諸計画が何時, どのような順序で実現をみるか

\section{表 4 カナダ・アサバスカのオイルサンド開発計画}

\begin{tabular}{|c|c|c|c|c|c|}
\hline & GCOS & Syncrude & Shell Canada & $\begin{array}{l}\text { Cities } \\
\text { Service }\end{array}$ & Muskeg \\
\hline 請 & 1962 受理 & 1969 受理 & 1963 & 1963 & 1969 \\
\hline 操 業 開 始（予定） & (1967) & (1977) & $(1980)$ & & \\
\hline 規 模, BCD (年) & $\begin{array}{l}51,000(' 72) \\
65,000(' 75)\end{array}$ & $\begin{array}{l}105.000(' 80) \\
125,000(' 84)\end{array}$ & 100,000 ('82) & 100,000 & 60,000 \\
\hline 採 掘 方 法 & 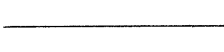 & - 露 天 & 掘 & 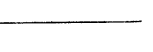 & 油層内回収 \\
\hline & $\begin{array}{l}\text { バケット・ホイー } \\
\text { ル・エクスカベー } \\
\text { ター }\end{array}$ & ドラッグ・ライン & ドラッグ・ライン & & \\
\hline 製 油 方 式 & $\begin{array}{c}\text { ディレード・ } \\
\text { コーキング }\end{array}$ & $\begin{aligned} \text { フルード・ } \\
\text { コーキング }\end{aligned}$ & $\begin{array}{l}\text { 水素化精製 } \\
\text { 水素化分解 }\end{array}$ & H一オイル & \\
\hline 合成原油収率, *1 \% & $\begin{array}{l}(80)(90)(65, \overline{78}) \\
\quad=47, \overline{56}\end{array}$ & $\begin{array}{l}(87)(91)(71, \overline{82}) \\
\quad=56, \overline{65}\end{array}$ & $48, \overline{67}$ & $\overline{71}$ & \\
\hline $\begin{array}{c}\text { 投 資本, } 10^{6} \mathrm{C} \$ \\
(\text { オンサト) }\end{array}$ & 260 & 900 & & & \\
\hline 規模あたり, C\$/BCD & $\begin{array}{c}4,500 \\
\text { @ } 65,000 \mathrm{BCD}\end{array}$ & $\begin{array}{c}7,000 \\
@ 125,000 \mathrm{BCD}\end{array}$ & & & \\
\hline
\end{tabular}

(注) *1. (採掘効率) (分離効率) (変換効率), 数字の上に一つきは容量パーセント, 一のないものは重 量パーセントを示す。 


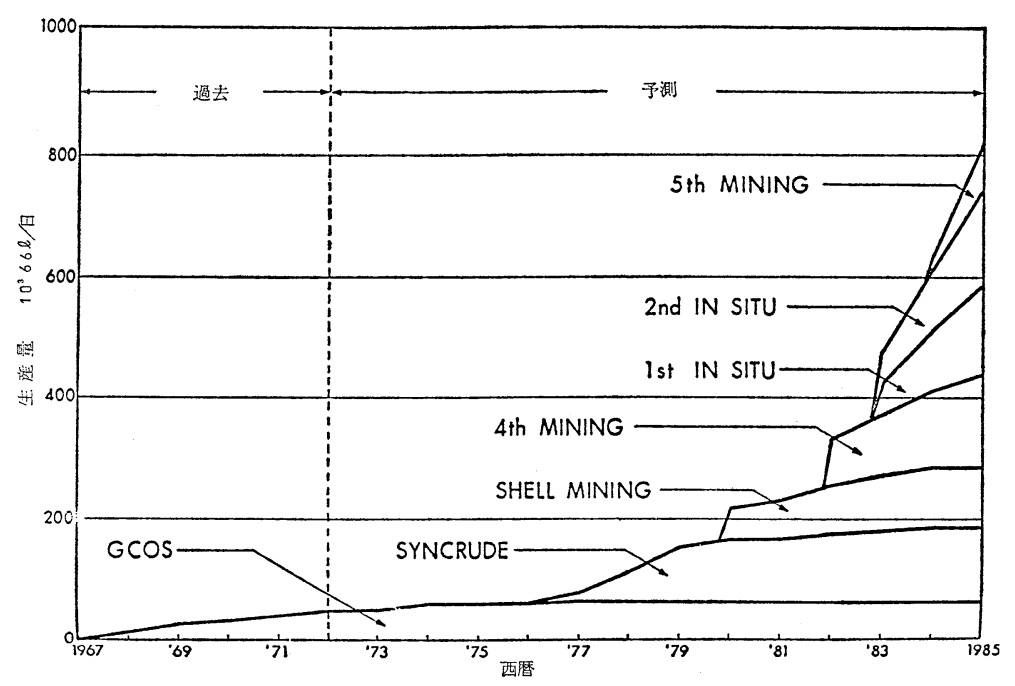

図 5 カナダのオイルサンド資源開発の将来予測

はアルバータ州政府ならびにカナダ連邦政府の判断 に依るところであり, 軽々しく予想はできないが, G. W. Govier 氏の個人的予測は図に示寸とおりであ る4)。

すなわち同氏によればアルバータ州の在来型石油生 産はほぼその限界に近づきつつあり, カナダ全国とし てはマッケンジーデルタ, 北極圈諸島, 東部海岸大陸 棚などにおける石油生産が将来有望ではあるが，カナ ダ自体の石油消費量の伸び (年率 4 5\%) およびアメ リカ合衆国の石油資源不足の拡大を考劣ると，アルバ ータのオイルサンド資源の重要性は大きいとし, 現在 のオイルサンドの確認可採埋蔵量（露天掘り分）は日 産 300 万 bbl までの生産を支えるのに十分であるとみ ている。

開発進展の制限因子となるのはむしろ莫大な資金調 達 $(10$ 万 bbl/日 のプラント建設のために約 8 億カナ ダドルを要する), プラント建設資材, 技術者, その 他の労働力などであろうという。

このような現実的制約を考えると，オイルサンドか らの合成原油の生産量は1980年に20万 bbl/日 を大き く越えることはないが1985年に80万 bbl/日 の水準に 達するであろら。図 5 はこのような見通しのもとで, あり得る開発計画の進展の姿を示したものである。

なお最近, 新聞の伝えるところによれば, アルバー タ州政府のユルコ環境相はエドモントンで開かれたオ イルサンド技術会議の席上で次のようなオイルサンド 開発基本計画を発表したという。すなわち (1) 70年代 後半に新たに日産10 12万 bbl のプラントを $1 \sim 2$ 基
建設する, (2) 80 年代前半は 2 年に 1 基のペース, (3) 80 年代後半から 90 年代にかけては 1 年 1 基のペースと

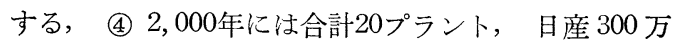
bbl を達成する。

この基本計画はすでに連邦政府との意見調整ずみと いわれ，図 5 に示した Govier 私見よりはややゆるい ペースである。この漸進的開発計画は, 余りにも早急 に開発を促進することによるカナダないしアルバータ 州の経済的混乱を回避することを趣旨としている，と 伝えられる。しかし同時に資源保全, 環境保全の世論 を反映したものとも想像される。

\section{5. むす び}

カナダおよびベネズエラ両国に主として賦存するオ イルサンド資源注計約 1 兆 5 千億 bbl という巨大な ものであり, 可採率 $20 \%$ を仮定すれば中東地域の石油 確認可採埋蔵量に比肩し得るものである。カナダにお いては1967年秋以来, 露天掘り工法により合成原油が 商業規模で生産されており, 技術的, 経済的なフィー ジビリティーはすでに実証された。今後の本格的開発 の進展のためには油層内採收技術の完成が必要であ る。またオイルサンド原油からの合成原油得率向上の ための精製技術の工夫, 副生硫黄の有効利用, バナジ ウムの除去とその活用などの課題が残されている。ま たオイルサンドと共存する石灰岩, 岩篮, 珪砂などの 鉱物資源の開発, 活用も検討されるべき問題である。 わが国のもつ総合的な科学技術力がこれら資源の開発 に役立ち, 彼の国の経済社会発展に寄与し, またわが 国のエネルギーならびに炭化水素資源輸入確保に貢献 
するような計画の実現する日の近いことを願って止ま ない次第である。

\section{文献}

1) 富永博夫, 燃料協会誌, 46, 653 (1967), 石油学 会誌，10，277 (1967)

2) 冨永博夫, 内外における新合成燃料の開発動向と 実用化上の技術的経済的諸問題, 日本技術経済七 ンター (1973)

3) M. W. Clegg, "New Sources of Oil-Oil Sands, Shales and Synthetics", Energy ; From Surplus to Scarcity? Ed. by K. A. D. Inglis, Applied Science Publishers, 1974

4) G. W. Govier, “Alberta's Oil Sands in the Energy Supply Picture”, Talk to 1973 C. S. P. G. Symposium entitled "Oil Sands-Fuel of the Future", Calgary, Alberta, Canada, Sept. 7, 1973

5) Anibal R. Martinez, Recuros de Hidrocarburos de Venezuela, 2nd Ed, 1973, Edreca Editores, Caracas

6) F. W. Camp, The Tar Sands of Alberta, Canada, Cameron Engineers, 1970

7) 玉野俊郎編，カナダのオイルサンド概況，ADI … 1184 (1974年 2 月 1 日)

8) A. W. Hyndman, 22 nd Canadian Chemical Engineering Conference, Sept., 1972, Tronto., 富永博夫, 功刀泰碩, 石油学会誌, 16, 815 (1973)

9) M. A. Carrigy and J. W. Cramers, Guide to the Athabasca Oil Sands Area, Alberta Research, Edmonton, Alberta (1973)

10）矢部孟, 日化協月報, 20, 1967年 5 月, 石油開発 時報，1968年12月

11）玉野俊郎，石油開発時報，1970年 8 月

12）平川誠一，石油技術協会誌，39，No.1 (1974)

13) 浜野英信, 同上, 39, No. 1 (1974)

\title{
Development of Oil Sands Resources
}

\author{
by Hiroo Tominaga
}

(Engineering Research Institute Faculty of Engineering

University of Tokyo)

SYNOPSIS :-Oil sands resources in Athabasca, Canada, and Orinoco oil belt, Venezuela, have been investigated. Their magnitude as bitumen in place is roughly comparable to that of conventional crude oil. The present proven technologies and some future technical developments required for extraction and up-grading of the potential hydrocarbon resources are discussed. Relevant commercial activities and their prospects in the near future are reviewed. 